\title{
Prevalence and factors associated with experience of intrafamilial violence by teenagers in school
}

\author{
Prevalência e fatores associados à vivência de violência intrafamiliar por adolescentes escolares
}

Prevalencia y factores asociados a la vivencia de violencia intrafamiliar por adolescentes escolares

\section{Rosana Santos Mota', Nadirlene Pereira Gomes', Fernanda Matheus Estrela', Melissa Almeida Silva', Jéssica Damasceno de Santana', Luana Moura Campos', Kátia Cordélia Cunha Cordeiro' \\ ' Universidade Federal da Bahia, Nursing School. Salvador, Bahia, Brazil.}

\section{How to cite this article:}

Mota RS, Gomes NP, Estrela FM, Silva MA, Santana JD, Campos LM, et al. Prevalence and factors associated with experience of intrafamilial violence by teenagers in school. Rev Bras Enferm [Internet]. 2018;71(3):1022-9. DOI: http://dx.doi.

org/10.1590/0034-7167-2016-0546

\section{Submission: 10-13-2016 Approval: 05-23-2017}

\begin{abstract}
Objective: To estimate prevalence of intrafamilial violence experience and its association with sociodemographic, sexual and use of alcohol/drugs variables in teenagers of a public school in Salvador, Bahia, Brazil. Method: Cross-sectional study with 239 teenagers. Data were collected through structured instrument, analyzed according to descriptive and inferential statistics, with multiple logistic regression. Results: Research pointed out a high prevalence of intrafamilial violence among teenagers $(60.67 \%)$. Experience of this grievance was associated, with statistical significance, with the variables: higher age range (PR $=$ 1.83 and $95 \% \mathrm{Cl}: 1.05-3.18)$ and regular use of condom ( $\mathrm{PR}=1.81$ and $95 \% \mathrm{Cl}: 1.06-3.08)$. Violence was also associated with consumption of alcohol and marijuana. Conclusion: Regular use of condom and consumption of alcohol and/or marijuana represent risk behaviors to the experience of intrafamilial violence by teenagers in school, especially older than 15 years old. Descriptors: Teenager; Domestic Violence; Drug Users; School Health; Nursing.
\end{abstract}

\section{RESUMO}

Objetivo: Estimar a prevalência de vivência de violência intrafamiliar e a sua associação com as variáveis sociodemográficas, sexuais e o uso de álcool/drogas em adolescentes de uma escola pública em Salvador, Bahia, Brasil. Método: Estudo transversal com 239 adolescentes. Os dados foram coletados através de instrumento estruturado, analisados conforme a estatística descritiva e inferencial, com regressão logística múltipla. Resultados: A pesquisa apontou uma elevada prevalência de violência intrafamiliar entre adolescentes $(60,67 \%)$. A vivência desse agravo associou-se, com significância estatística, com as variáveis: maior faixa etária $(R P=1,83$ e IC95\%: 1,05 - 3,18) e fazer uso regular de preservativo ( $R P=1,81$ e IC95\%: 1,06 - 3,08). A violência também foi associada ao consumo de álcool e maconha. Conclusão: $\mathrm{O}$ uso regular de preservativo e o consumo de álcool e/ou maconha representa comportamentos de risco para a vivência de violência intrafamiliar por escolares, sobretudo acima de 15 anos.

Descritores: Adolescente; Violência Doméstica; Usuários de Drogas; Saúde Escolar; Enfermagem.

\section{RESUMEN}

Objetivo: Estimar la prevalencia de vivencia de violencia intrafamiliar y su asociación con las variables sociodemográficas, sexuales y el uso de alcohol/drogas en adolescentes de una escuela pública en Salvador, Bahía, Brasil. Método: Estudio transversal con 239 adolescentes. Los datos fueron recogidos a través de instrumento estructurado, analizados de acuerdo con la estadística descriptiva e inferencial, con regresión logística múltiple. Resultados: La investigación indicó una elevada prevalencia de violencia intrafamiliar entre adolescentes (el 60,67\%). La vivencia de ese agravio se asoció, con significancia estadística, con las variables: mayor franja etaria $(\mathrm{RP}=1,83$ y IC95\%: 1,05 - 3,18) y hacer el uso regular de condón ( $\mathrm{RP}=1,81$ y IC95\%: 1,06 - 3,08). La violencia también fue asociada al consumo de alcohol y marihuana. Conclusión: El uso regular de condón y el consumo de alcohol y/o marihuana representa comportamientos de riesgo para la vivencia de violencia intrafamiliar por escolares, sobre todo arriba de 15 años.

Descriptores: Adolescente; Violencia Doméstica; Usuarios de Drogas; Salud Escolar; Enfermería. 


\section{INTRODUCTION}

Considered as a violation of rights, intrafamilial violence experienced by teenagers represents a public health problem, whose damages require actions to prevent this phenomenon, as well as to reduce the impact of such on people's quality of life.

The term intrafamilial violence is characterized by the imbalance of power that is manifested in relationships between the members of a family. This type of violence comprises family members or people with parental role, even if without bonds of consanguinity, with possibility of occurrence, including in public space. Epistemologically, it differs from the domestic violence, because such is restricted to the physical space of the house, and can involve other people living together, such as employees, aggregates and other individuals who visit the domicile even if sporadically ${ }^{(1-2)}$.

The phenomenon of violence consists of any action or omission that endangers the physical and/or mental well-being, freedom and full development of an individual. Regarding children and teenagers, this damage can even be more intense, since adolescence is considered one of the most troubled moments of the human development, marked by emotional transformations of awkwardness and uneasiness, which contribute to the building of their own identity ${ }^{(3)}$. Thus, regardless of the form of expression, the experience of intrafamilial violence affects the lives of teenagers, and can result in repercussions of physical, mental and social nature.

Considering the physical nature, national and international research have identified a variety of injuries, such as hematomas, abrasions, fractures, among others ${ }^{(2-4)}$. Taking into account the impairment on mental health, teenagers may show aggressive behavior, memory changes, feelings of helplessness, tendency to trigger psychosomatic symptoms, fear, low self-esteem, sadness and depression. Influenced by repercussions of psychological nature, in the social field it has been revealed poor school performance and inability to maintain interpersonal relationships ${ }^{(2-4)}$. In addition to the vulnerability to other risks such as Sexually Transmitted Infections (STIs), unintended pregnancy ${ }^{(5)}$ and use/abuse of alcohol and/or other drugs, the latter being considered as an escape from the unfavorable social reality ${ }^{(6-7)}$. Thus, we can perceive a series of events to which teenagers are exposed due to a family life permeated by violence.

Also, we must mention the impacts of intrafamilial violence on the health sector. In the United States of America, $8.6 \%$ of young people aged between 10 and 24 years, received treatment in emergency departments for injuries arising from physical aggression ${ }^{(8)}$. In Brazil, within every 100 thousand treatments related to violence in the scope of the Brazilian Unified Health System (SUS) in 2011, 25\% of the cases referred to the age group between 10 and 19 years, which equals 25,156 teenagers in situations of violence that demanded health care. In the Northeast region of Brazil, the experience of this grievance is even higher: within every 100 thousand treatments, 4,776 teenagers sought the health service due to causes associated with violence, representing $29.8 \%$ of the total of cases in the region. Bahia was responsible for 1,364 treatments, value corresponding to $34.7 \%$ of the total, percentage above the regional and national index ${ }^{(9)}$.

Considering the complexity and magnitude of the phenomenon, scholars from various fields of knowledge dedicate themselves to the production of a knowledge that allows them to broaden the knowledge related to social and health aspects experienced by teenagers, exemplified by the use of alcohol and other drugs in adolescence ${ }^{(10-11)}$. In this context, we question: What is the prevalence of intrafamilial violence experience? Is there an association between this grievance and the sociodemographic, sexual and use of alcohol/drugs variables? Starting from the hypothesis of the existence of this relation, we believe that knowing the factors associated with intrafamilial violence experience can direct to the profile of students more vulnerable to the problematic, which social interventions must be prioritized.

\section{OBJECTIVE}

To estimate prevalence of intrafamilial violence experience and its association with sociodemographic, sexual and use of alcohol/drugs variables in teenagers of a public school in Salvador, Bahia, Brazil.

\section{METHOD}

\section{Ethical aspects}

The research respected the ethical principles in the Resolution no. 466/2012, which deals with ethical issues concerning research involving human subjects. The project was approved by the Research Ethics Committee of the Nursing School of the Federal University of Bahia (CEPEE/UFBA). All teenagers and their legal representatives signed the terms of Free and Clarified Consent and Assent, respectively.

\section{Study design, location and period}

Cross-sectional study, carried out in a public high school located in a peripheral district of the city of Salvador, capital of Bahia State. Data collection was held between October 2014 and January 2015.

Research is related to the Study Group "Violência, Saúde e Qualidade de Vida" (Violence, Health and Quality of Life). Specifically related to the source project named: "Universidade e escola pública: buscando estratégias para enfrentar os fatores que interferem no processo ensino/aprendizagem" (University and public school: seeking strategies to face factors that interfere in the teaching/learning process), under financing of Fundação de Amparo à Pesquisa do Estado da Bahia (Bahia Research Foundation - FAPESB). The source project is an action research, whose aim was to analyze and to intervene in social/relational situations (violence, alcohol/drugs, prejudice/ discrimination) that interfere with the teaching-learning process of students enrolled in an institution of public education.

\section{Population or sample; inclusion and exclusion criteria}

A total of 239 students participated in the study. The institution offers vacancies for middle school students from 
grades 6 to $9^{1}$. Currently, it is the field of practice for graduates in nursing and other healthcare courses of the Federal University of Bahia, through the curricular component: "Atividade curricular em comunidade e sociedade (ACCS) - Abordagem interdisciplinar e transdisciplinar dos problemas de saúde relacionados à violência" (Curricular activity in community and society (ACCS) - Interdisciplinary and transdisciplinary approach of health issues related to violence). Such partnership provides approach to the study place.

For data collection, a stratified sampling plan proportional to the number of students per class was carried out. This resulted in a minimum sample of 210 students, representative of the institution, with a maximum sampling error of $2.35 \%$. In each class, the minimum of students suggested by sampling plan was included in the study. Inclusion criteria were: to belong to the age group between 10 to 19 years and be regularly enrolled at the institution. Teenagers that, for two consecutive times, missed school in the corresponding days to the collection were excluded. A sample of 239 students was totaled up.

\section{Study protocol}

Data collection was carried out by the researcher and a team formed by students of nursing and other healthcare courses, which are related to the Study Group "Violência, Saúde e Qualidade de Vida" (Violence, Health and Quality of Life) or to the Componente Curricular ACCS (ACCS Curricular Component).

Data were obtained through a form developed to achieve the objectives of the source project. It is a structured form consisting of six blocks that include: sociodemographic and economic variables, sexual and reproductive health, use of alcohol and drugs, bullying experience and intrafamilial violence story. To this end, two validated and widely used forms were applied: the Drug Use Screening Inventory (DUSI) and the Escala de Vitimização e Agressão entre Pares (Scale of Victimization and Aggression between Pairs - EVAP).

Aiming to achieve the objective proposed in this study, it was established as outcome variable the intrafamilial violence experience, which was categorized into "Yes" and "No" according to the following question: Has someone of your family done any of these things with you? Curses / Humiliation; Pinch / Slap; Kick / Punch; Stab / Shot / Burn; Touched your body (breasts or genitalia); Had sex with you without your will. To carry out the criterion of violence experience, it was considered the report of the event in the options "sometimes", "very often" or "always", as assertion of the Likert scale.

The independent variables were: drug consumption, with "Yes" and "No" categories, emerged from the answers of teenagers to DUCl, which considers the substance consumption in the last 30 days prior to the interview; familial conviviality, related to the experience or non-experience with both parents; work and sexual and reproductive aspects (sexual relation, use of condom, pregnancy), also dichotomized in "Yes" and "No", and sociodemographic aspects, such as age, categorized up to $14 / 15$ years old or more, according to criteria used in literature ${ }^{(9-12)}$; sex; religion, considering the assertion without distinction between religious diversities; race, grouped into "black", to those self-identified as Black and Two or More Races, and "white", to those self-identified as White and Asian, considering the categories defined by the Brazilian Institute of Geography and Statistics (IBGE).

\section{Analysis of the results and statistics}

Data was organized through the Microsoft Excel 2007 program, constituting the database. Subsequently, data were transported to the Stata version 12 program, where the statistical analysis was carried out. Descriptive data were reported as frequencies and percentages. Magnitude of the association between variables was expressed as prevalence ratio (PR) and respective confidence intervals of 95\% (95\% $\mathrm{Cl})$. Thereafter, logistic regression was applied to obtain the estimates of Odds Ratio and respective confidence intervals at $95 \%$, with adjustment for variables, using the backward Euler method.

\section{RESULTS}

Prevalence of intrafamilial violence among the 239 students was of $60.67 \%$. When segmented by type of manifestation, it was evident that the physical expression of violence $(49.38 \%)$ was the most frequent, followed by psychological $(31.38 \%)$ and sexual (1.67\%) violence.

According to Table 1, most teenagers exposed to intrafamilial violence experience were men $(62.02 \%)$, equal to or older than 15 years old $(67.71 \%)$, self-identified as nonblack $(64.29 \%)$. They declared that had no specific religion $(62.99 \%)$, lived with both parents $(61.68 \%)$, financially contributed to the sustenance of the family $(72.73 \%)$ and had not initiated sexual activities (61.18\%). In bivariate analysis, within variables studied, there outstands a positive association between alcohol consumption in the last month (PR $=1.20$ and $95 \% \mathrm{Cl}: 0.65-2.19)$, older age $(\mathrm{PR}=1.65 \mathrm{e}$ $95 \% \mathrm{Cl}: 0.96-2.83)$, work ( $\mathrm{PR}=1.77$ and $95 \% \mathrm{Cl}: 0.45-$ $6.85)$ and regular use of condom $(\mathrm{PR}=1.70$ and $\mathrm{Cl} 95 \%$ : 0.88 - 3.30) with violence experience.

Multivariate analysis (Table 2) points out, in the initial model, for a positive association, with statistical significance, between the intrafamilial violence experience and age older than or equal to 15 years old $(\mathrm{PR}=1.83$ and $95 \% \mathrm{Cl}$ : 1.04 - 3.22). It is also evidenced a borderline association between violence and frequent use of condoms ( $P R=1.73$ and $95 \% \mathrm{Cl}: 1.00-2.99)$. In the final model, the statistically significant association with both covariates is maintained.

Regarding the violence expressions (Table 3), the study showed that $32 \%$ of teenagers with a history of psychological violence declared have used alcohol in the last month. Smaller

1 Translator's note - Brazilian middle school lasts four years, with students usually aged between 11 and 15 years old. 
proportion was found among the teenagers who experienced physical violence and consumed such substance $(26.27 \%)$. No teenager with history of sexual violence referred to the consumption of alcohol. It was also identified a positive association between alcohol consumption and experience of psychological $(\mathrm{OR}=1.61$ and $95 \% \mathrm{Cl}: 0.87-2.96)$ and physical $(\mathrm{OR}=1.08$ e $95 \% \mathrm{Cl}: 0.60-1.93)$ violence.

Table 1 - Prevalence and prevalence ratios with respective $95 \%$ confidence interval to associations between intrafamilial violence experience in teenagers and variables of the study, Salvador, Bahia, Brazil, 2015

\begin{tabular}{|c|c|c|c|c|}
\hline Variables & $\begin{array}{l}\text { Total } \\
\text { no. }\end{array}$ & $\begin{array}{l}\text { Intrafamilial } \\
\text { violence (\%) }\end{array}$ & $\begin{array}{c}\text { Prevalence } \\
\text { Ratio (PR) }\end{array}$ & $\begin{array}{c}\mathrm{Cl} \\
(95 \%)\end{array}$ \\
\hline \multicolumn{5}{|l|}{ Alcohol } \\
\hline No & 178 & 59.55 & 1 & \\
\hline Yes & 61 & 63.93 & 1.20 & $0.65-2.19$ \\
\hline \multicolumn{5}{|l|}{ Sex } \\
\hline Male & 129 & 62.02 & 1 & \\
\hline Female & 110 & 59.09 & 0.88 & $0.52-1.48$ \\
\hline \multicolumn{5}{|c|}{ Age } \\
\hline 10 to 14 years old & 143 & 55.94 & 1 & \\
\hline 15 to 19 years old & 96 & 67.71 & 1.65 & $0.96-2.83$ \\
\hline \multicolumn{5}{|l|}{ Race } \\
\hline Nonblack & 56 & 64.29 & 1 & \\
\hline Black & 183 & 59.56 & 0.81 & $0.83-1.52$ \\
\hline \multicolumn{5}{|l|}{ Religion } \\
\hline Yes & 112 & 58.04 & 1 & \\
\hline No & 127 & 62.99 & 1.23 & $0.73-2.07$ \\
\hline \multicolumn{5}{|l|}{ Family conviviality } \\
\hline Parents & 107 & 61.68 & 1 & \\
\hline Others & 132 & 59.85 & 0.92 & $0.54-1.56$ \\
\hline \multicolumn{5}{|l|}{ Work } \\
\hline Yes & 11 & 72.73 & 1 & \\
\hline No & 228 & 60.09 & 1.77 & $0.45-6.85$ \\
\hline \multicolumn{5}{|l|}{ Sexual relation } \\
\hline No & 152 & 61.18 & 1 & \\
\hline Yes & 87 & 59.77 & 1.06 & $0.61-1.81$ \\
\hline \multicolumn{5}{|l|}{ Pregnancy } \\
\hline No & 234 & 60.68 & 1 & \\
\hline Yes & 5 & 60.00 & 0.97 & $0.15-5.92$ \\
\hline \multicolumn{5}{|l|}{ Condom } \\
\hline No & 195 & 63.08 & 1 & \\
\hline Yes & 44 & 50.00 & 1.70 & $0.88-3.30$ \\
\hline
\end{tabular}

Data expressed in Table 4 showed a positive association between psychological violence and consumption of marijuana $(\mathrm{PR}=6.79$ and $95 \% \mathrm{Cl}: 0.69-66.40)$. It stands out that, among four (4) teenagers who referred to the use of this drug, $75 \%$ had a history of psychological violence experience. Physical expression of violence was also associated with the use of this substance ( $\mathrm{PR}=3.13$ and $95 \% \mathrm{Cl}: 0.32-30.53)$. It is important to emphasize that $75 \%$ of teenagers who referred to consumption of marijuana had experience with physical violence.

Table 2 - Odds ratio and respective 95\% confidence interval to associations between intrafamilial violence experience in teenagers and variables of the study, Salvador, Bahia, Brazil, 2015

\begin{tabular}{|c|c|c|c|}
\hline Variables & & $\begin{array}{l}\text { Initial model } \\
\text { OR } 95 \% \mathrm{Cl}\end{array}$ & $\begin{array}{l}\text { Final model } \\
\text { OR 95\%Cl }\end{array}$ \\
\hline \multicolumn{4}{|l|}{ Alcohol } \\
\hline & Yes & $1.18(0.61-2.26)$ & - \\
\hline \multicolumn{4}{|l|}{ Age } \\
\hline & $\begin{array}{l}15 \text { to } 19 \\
\text { years old }\end{array}$ & $1.83(1.04-3.22)$ & $1.83(1.05-3.18)$ \\
\hline \multicolumn{4}{|l|}{ Sex } \\
\hline & Female & $0.96(0.54-1.69)$ & - \\
\hline \multicolumn{4}{|l|}{ Race } \\
\hline & Negra & $0.82(0.43-1.57)$ & - \\
\hline \multicolumn{4}{|l|}{ Religion } \\
\hline & No & $1.23(0.71-2.12)$ & - \\
\hline \multicolumn{4}{|c|}{ Who they live with } \\
\hline & Others & $1.05(0.59-1.85)$ & - \\
\hline \multicolumn{4}{|l|}{ Work } \\
\hline & No & $1.15(0.91-1.45)$ & - \\
\hline \multicolumn{4}{|l|}{ Sexual relation } \\
\hline & Yes & $0.33(0.81-1.34)$ & - \\
\hline \multicolumn{4}{|l|}{ Pregnancy } \\
\hline & Yes & $1.13(0.16-8.10)$ & - \\
\hline Condom & Yes & $1.73(1.00-2.99)$ & $1.81(1.06-3.08)$ \\
\hline
\end{tabular}

Table 3 - Prevalence and prevalence ratios for associations between manifestations of intrafamilial violence and consumption of alcohol by teenagers, Salvador, Bahia, Brazil, 2015

\begin{tabular}{lcccc}
\hline \multicolumn{1}{c}{ Variables } & $\begin{array}{c}\text { Total } \\
\text { no. }\end{array}$ & $\begin{array}{c}\text { Consumption } \\
\text { of alcohol (\%) }\end{array}$ & $\begin{array}{c}\text { Prevalence } \\
\text { Ratio (PR) }\end{array}$ & Cl (95\%) \\
\hline $\begin{array}{l}\text { Psychological violence } \\
\text { Yes }\end{array}$ & 75 & 32.00 & 1.61 & $0.87-2.96$ \\
$\quad$ No & 164 & 22.56 & 1 & \\
$\begin{array}{l}\text { Physical violence } \\
\text { Yes }\end{array}$ & 118 & 26.27 & 1.08 & $0.60-1.93$ \\
$\quad$ No & 121 & 24.79 & & \\
$\begin{array}{l}\text { Sexual violence } \\
\text { Yes }\end{array}$ & & & & \\
$\quad$ No & 4 & 0.0 & & \\
& 235 & 25.96 & & \\
\hline
\end{tabular}


Table 4 - Prevalence and prevalence ratios for associations between manifestations of intrafamilial violence and consumption of marijuana by teenagers, Salvador, Bahia, Brazil, 2015

\begin{tabular}{lcccc}
\hline \multicolumn{1}{c}{ Variáveis } & $\begin{array}{c}\text { Total } \\
\text { no. }\end{array}$ & $\begin{array}{c}\text { Consumption } \\
\text { of marijuana (\%) }\end{array}$ & $\begin{array}{c}\text { Prevalence } \\
\text { Ratio (PR) }\end{array}$ & $\mathbf{C l}$ (95\%) \\
\hline $\begin{array}{l}\text { Psychological violence } \\
\text { Yes }\end{array}$ & 75 & 4.00 & 6.79 & $0.69-66.40$ \\
No & 164 & 0.61 & 1 & \\
& & & & \\
$\begin{array}{l}\text { Physical violence } \\
\text { Yes }\end{array}$ & 118 & 2.54 & 3.13 & $0.32-30.53$ \\
$\quad$ No & 121 & 0.83 & 1 & \\
$\begin{array}{l}\text { Sexual violence } \\
\text { Yes }\end{array}$ & & & & \\
No & 4 & 0.00 & & \\
& 235 & 1.70 & & \\
\hline
\end{tabular}

\section{DISCUSSION}

Prevalence of intrafamilial violence among teenagers $(60.67 \%)$ showed in the study agrees with the Brazilian research held in São Paulo, with 269 teenagers whose proportion was of $72.3 \%{ }^{(13)}$ and with data from the United Nations Children's Fund (UNICEF), which estimates that six in every ten children/teenagers in the world are victims of this grievance $^{(12)}$. A study carried out in Romania, with 869 adults, also indicates similar prevalence $(53.7 \%)^{(14)}$. In India, a research with teenagers in school from a peripheral district identified a lower prevalence $(38.1 \%)$, even though the country has a Human Development Index (HDI) lower than the Brazilian $\mathrm{HDI}^{(15)}$. Experience of violence in the family is configured because it is in a worldwide reality that does not depend on the degree of human development in the country.

Regarding the sex, the study points to a more expressive prevalence in the male audience to the violence experience in the family scope. Higher prevalence of boys $(62.02 \%)$ also finds support in other national, held in Curitiba and Recife ${ }^{(16-17)}$, and international studies, according to the survey conducted in India, with a public of similar characteristics ${ }^{(15)}$. Higher exposure of the male public to the grievance can be related to the social construction of masculinity. It stimulates more challenging and fearless behaviors among men, leaving them more exposed to suffer violence in the family context ${ }^{(18)}$.

Other association of intrafamilial violence experience refers to the regular use of condom. We infer that the regularity in use of condom facilitates its discovery by the representatives, causing them to deduce the teenager's sexual initiation. Therefore, we believe that the violence is not expressed due to the use of condom, but by the discovery that the teenager initiated the sexual life, being such a cause for family conflicts.

Besides the expressiveness of intrafamilial violence in males, we point to a higher exposure among teenagers in age group over 15 years old $(67.71 \%)$. However, an international study believes that, depending on the violence manifestation, such stands out in different age groups: teenagers with younger age are more exposed to physical violence, while those with older age are more exposed to psychological violence ${ }^{(15)}$.

Study also shows that, though still teenagers, some already work and collaborate with the sustenance of the family. This represents a factor of protection against experience of intrafamilial violence. These data are ratified in a study conducted in the Brazilian southeast, which points out that, through remunerative work, teenagers gain more autonomy and freedom in relation to their parents ${ }^{(19)}$. This context reduces cases of intrafamilial violence. Regarding the international level, in a survey conducted in West Bank and East Jerusalem, with 1,930 students from schools, it was stated a lower association of violence with those who performed remunerative work ${ }^{(20)}$, which supports our findings. Therefore, we can infer that, to have some financial resource configures a protection for the teenager against intrafamilial violence.

Although it was not established the association between family arrangements and experience of intrafamilial violence, we identified a high proportion of violence in both teenagers who lived with both parents, as in the ones residing with other family forms. This denotes the high exposure of teenagers to intrafamilial violence, regardless of consanguineous ties. Even though they are not reported in this study, Brazilian ${ }^{(13,20-22)}$ and international ${ }^{(13,20)}$ research affirm that parents are the main perpetrators of intrafamilial violence against children and teenagers.

Another factor that weakens the teenager to violence experience is the absence of religious bond. Corroborating, a study conducted in the United States defends that having religion reduces the likelihood of teenagers developing violent behavior $^{(23)}$. In the Brazilian scenario, a study carried out with the database of the States of Ceará, Espírito Santo, Pará and Rio Grande do Sul, found an association between religion and low-risk behavior ${ }^{(24)}$, ratifying that being adept to a religion is a protective factor for the violence experience.

Regarding race, the study pointed out a higher exposure to the violence experience by teenagers self-identified as whites. However, the experience of intrafamilial violence among teenagers of black race is confirmed in several national and international surveys ${ }^{(8,22,25-26)}$. We emphasize that this population is also vulnerable to other grievances, such as the use of alcohol and other drugs, as stated in our study.

Considering the use of marijuana, we are alarmed by the high percentage of teenagers who made use of this substance and presented history of psychological violence (75\%), the same ratio presented in physical violence. In Brazil, a national study with teenagers from public and private education also identified an association between the various forms of violence manifestations with the consumption of marijuana(6). A study carried out in North Carolina, with 37 teenagers in age group between 16 to 19 years old, pointed to a relation between the use of marijuana, from 13 years old, with an inclination for the experience of physical and emotional abuse in their families ${ }^{(25)}$.

Regarding the use of alcohol and/or other drugs in Natal, Rio Grande do Norte, Brazil, a study conducted with 463 teenagers identified an association between domestic violence and this grievance, pointing out that, among the investigated, 
91\% reported suffering violence, of which $23.8 \%$ make use of alcohol and other drugs ${ }^{(27)}$. A South African study draws attention to the use of alcohol and other drugs at an early age and believes that this conduct is related to the family context permeated by violence ${ }^{(6)}$. Violence experiences in the family increase the vulnerability of the teenager to social problems such as abuse of illicit psychoactive substances ${ }^{(5-6)}$. Therefore, we can perceive that consumption of alcohol and other drugs is adopted as a crutch in the face of violent family relationships, increasing the possibility of consuming other psychoactive substances. Considering that our study does not allow us to identify the relation of causality between the variables, we should consider experience of intrafamilial violence as a consequence of conflicts related to the use of drugs by teenagers.

Thus, it is essential the implementation of health education actions, especially in the context of Primary Health Care $(\mathrm{PHC})^{(28)}$. Therefore, the articulation with sectors of education is presented as advantageous strategy. Such can be implemented through the School Health Programme (SHP), which has as one of its principles the promotion of culture of peace and nonviolence ${ }^{(29)}$. We believe that, within the framework of the Estratégia Saúde da Família (Brazil's Family Health Strategy - ESF), the health-school articulation will promote the identification of children and teenagers at risk and/or intrafamilial violence and the development of actions that ensure these, a life free of violence.

\section{Study limitations}

Research is limited by the fact that the design of our study does not establish a relation of causality between the variables, signaling to the relevance of investigations that contemplate such a gap.

\section{Contributions to the fields of Nursing, health, or public policies}

In view of the repercussions of intrafamilial violence to teenagers' health and life, - among which the use of alcohol and other drugs - our study, when pointing out factors that interrelate with the phenomenon, may subsidize both actions for prevention of such and for reduction of damages associated with this grievance. Health professionals are essential in the process of confronting violence, emphasizing the nurses working in the PHC scenery, due to the opportunity of more frequent contact with individuals, including teenagers.

It would be important the insertion of intrafamilial violence theme in the curricula of degree courses and proposals for in-service training aiming to sensitize health professionals to the grievance problematics, as well as the recognition of associated factors, which will direct confrontation actions of the phenomenon.

\section{CONCLUSION}

Our study points out a high prevalence of intrafamilial violence among teenagers. Highest exposure involves males, selfidentified as nonblack, who lived with both parents, of older age group and made regular use of condoms. We identified a statistical significance for the latter two variables. There was also a positive association with consumption of alcohol and marijuana in the last month prior to the survey. Such findings contribute to evidence the factors associated with intrafamilial violence, which are as indicators for intervention.

We believe that one can create, from these factors, actions to prevent/confront the phenomenon, being the educational institutions privileged scenarios once frequent contact with teenagers favors the identification of groups at risk, whether by recognition that they experienced intrafamilial violence or by fitting in the profile identified by the study as the best chance for the experience of the grievance. In this process, we should stand out the SHP, considering its cross-sectional nature with $\mathrm{PHC}$, guideline of the health care of the population.

\section{FUNDING}

Project financed by the Fundação Amparo à Pesquisa do Estado da Bahia (Bahia Research Foundation - FAPESB).

\section{REFERENCES}

1. Moreira MIC, Sousa SMG. Violência intrafamiliar contra crianças e adolescentes: do espaço privado à cena pública. Rev Soc Quest [Internet]. 2012 [cited 2016 Aug 08];15(28):13-26. Available from: http://osocialemquestao.ser.puc-rio.br/media/2artigo.pdf

2. Almeida AA, Miranda OB, Lourenco LM. Domestic/intra-family violence against children and adolescents: a bibliometric review. Rev Interinst Psic[Internet]. 2013[cited 2016 Jun 08];6(2):298-11. Available from: http://pepsic.bvsalud.org/pdf/gerais/v6n2/v6n2a11.pdf

3. Assis SG, Avanci JQ, Duarte CS. Adolescence and public health: the thin line between a protagonist approach and risk for youths. Ciênc Saúde Colet[Internet]. 2015[cited 2016 Mar 06];20(11):3296. Available from: http://www.scielo.br/pdf/csc/v20n11/1413-8123CSC-20-11-3296.pdf

4. Mota RS, Gomes NP, Rodrigues AD, Camargo CL, Couto TM, Diniz NMF. History of childhood violence in the perspective of pregnant adolescents. Rev Eletr Enf [Internet]. 2014 [cited 2016 Jun 15];16(3):583-89. Available from: https://revistas.ufg.br/fen/article/ view/22109

5. Ceolin R, Dalegrave D, Argenta C, Zanatta EA. Situaciones de vulnerabilidad vividas en la adolescencia: revisión integradora. Rev Baiana Saúde Pública [Internet]. 2015 [cited 2016 Jul 22];39(1):150-63. Available from: http://inseer.ibict.br/rbsp/index.php/rbsp/ article/view/74

6. Horta RL, Horta BL, Costa AWN, Prado RR, Oliveira-Campos M, Malta DC. Lifetime use of illicit drugs and associated factors among Brazilian schoolchildren, National Adolescent School-based Health Survey (PeNSE 2012). Rev Bras Epidemiol [Internet]. 2014 [cited 2016 Jul 25];17(Supl-1):31-45. Available from: http://www.scielo.br/pdf/rbepid/v17s1/1415-790X-rbepid-17-s1-00031.pdf 
7. Davies PJ, Dreyer Y. A pastoral psychological approach to domestic violence in South Africa. HTS Teol Stud[Internet]. 2014[cited 2016 Jul 25];70(3):1-8. Available from: http://www.hts.org.za/index.php/HTS/article/view/2802

8. Kann L, Kinchen S, Shanklin SL, Flint KH, Hawkins J, Harris WA, et al. Morbidity and mortality weekly report. CDC Prev[Internet]. 2014 [cited 2016 Jul 23];63(4):2-47. Available from: https:/www.cdc.gov/mmwr/pdf/ss/ss6304.pdf

9. Waiselsz JJ. Mapa da violência 2012: crianças e adolescentes do Brasil. Centro Bras Est Lat-Am [Internet]. 2012 [cited 2015 Nov 15];(1). Available from: http://www.mapadaviolencia.org.br/pdf2012/MapaViolencia2012_Criancas_e_Adolescentes.pdf

10. Cardoso LRD, Malbergier A. Problemas escolares e o consumo de álcool e outras drogas entre adolescentes. Psicol Esc Educ[Internet]. 2014[cited 2015 Jul 01];18(1):27-34. Available from: http://www.scielo.br/pdf/pee/v18n1/v18n1a03.pdf

11. Orpinas P, Raczynski K. School climate associated with school dropout among tenth graders. Pensam Psicol Cali[Internet]. 2016[cited 2016 Jun 20];14(1):9-20. Available from http://dx.doi.org/10.11144/Javerianacali.PPSI14-1.scsd

12. UNICEF. Ocultos a plena luz: Un análisis estadístico de la violencia contra los niños. Relatório de 2014. UNICEF [Internet]. ISBN 97892-806-4767-9. Available from: http:/www.unicef.es/sites/www.unicef.es/files/informeocultosbajolaluz_0.pdf

13. Garbin CAS, Queiroz APCDG, Rovida TAS, Saliba O. A violência familiar sofrida na infância: uma investigação com adolescentes. Psicrev[Internet]. 2012 [cited 2016 Jun 06];18(1):107-18. Available from: http://pepsic.bvsalud.org/scielo.php?script=sci arttext\&pid $=$ S1677-11682012000100009\&Ing $=$ pt\&nrm $=$ iso

14. Rada C. Violence against women by male partners and against children within the family: prevalence, associated factors, and intergenerational transmission in Romania, a cross-sectional study. BMC Public Health [Internet]. 2014[cited 2015 Oct 10];14:1-15. Available from: http://www.ncbi.nlm.nih.gov/pmc/articles/PMC3933273/

15. Hiremath R, Debaje SP. Assessment of prevalence of domestic violence and mental health profile of adolescents exposed to domestic violence in an urban slum in Mumbai. Int J Res Med Scien [Internet]. 2014[cited 2016 Jul 28];2(1):290-92. Available from: http://www. scopemed.org/fulltextpdf.php?mno $=48308$

16. Fonseca RMGS, Egry EY, Nóbrega CR, Apostólico MR, Oliveira RNG. Reincidência da violência contra crianças no Município de Curitiba: um olhar de gênero. Acta Paul Enferm[Internet]. 2012 [cited 2016 Jun 07];25(6):895-01. Available from: http://www.unifesp. br/acta/pdf/v25/n6/v25n6a11.pdf

17. Silva MCM, Brito AM, Araújo AL, Abath MB. Characterization of cases of physical, psychological and sexual violence and negligence reported in Recife, Pernambuco. Epidem Serv Saúde[Internet]. 2012[cited 2016 Jun 09];22(3):403-12. Available from: http://scielo.iec. gov.br/pdf/ess/v22n3/v22n3a05.pdf

18. Hearn J. Introduction: international studies on men, masculinities, and gender equality men and masculinities. Men Masc[Internet] 2014[cited 2017 Mar 25];17(5):455-66. Available from: http://journals.sagepub.com/doi/citedby/10.1177/1097184X14558232

19. Sobrosa GMRS, Camerin C, Perrone CM, Dias ACG. Opinions about work of young people from lower social classes. Rev Bras Orient Prof[Internet]. 2013 [cited 2016 Jun 06];14(2):265-76. Available from: http://pepsic.bvsalud.org/pdf/rbop/v14n2/11.pdf

20. Leshem B, Haj-Yahia M, Guterman NB. The role of family and teacher support in post-traumatic stress symptoms among palestinian adolescents exposed to community violence. J Child Fam Stud [Internet]. 2016[cited 2016 Aug 08];25(2):488-02. Available from: http://journals.sagepub.com/doi/abs/10.1177/0306624X18759624

21. Gawryszewski VP, Valencich DMO, Carnevalle CV, Marcopito LF. Child and adolescent abuse in the state of São Paulo, Brazil, 2009. Rev Assoc Méd Bras[Internet]. 2012 [cited 2016 Jun 06];58(6):659-65. Available from: http://www.scielo.br/pdf/ramb/v58n6/en_ v58n6a09.pdf

22. Rodrigues CL, Gorios C, Gerolla V, Souza RM, Maso B, Armond JE. Notifications of violence against adolescents treated at a teaching hospital in the southern suburbs of São Paulo, 2011. Adolesc Saúde[Internet]. 2014[cited 2016 Jun 09];11(2):33-9. Available from: http://www.adolescenciaesaude.com/detalhe artigo.asp?id=443

23. Wright CPS, Vaughn MG, Maynard BR. Religiosity and violence among adolescents in the United States: findings from the national survey on drug use and health 2006-2010. J Interpers Viol [Internet]. 2014[cited 2016 Jul 25];29(7):1178-200. Available from: https:// www.ncbi.nlm.nih.gov/pmc/articles/PMC4049526/

24. Zappe JG, Dell'aglio DD. Variáveis pessoais e contextuais associadas a comportamentos de risco em adolescentes. J Bras Psiq Bras[Internet]. 2016[cited 2016 Aug 08];65(1):44-52. Available from: http://www.scielo.br/pdf/jbpsiq/v65n1/0047-2085-jbpsiq-65-1-0044.pdf

25. Wechsberg WM, Doherty IA, Browne FA, Kline TL, Carry MG, Raiford JL, et al. Gang membership and marijuana use among African American female adolescents in North Carolina. Substan Abuse Rehabil[Internet]. 2015[cited 2016 Jul 25];29(7):1178-200. Available from: https://www.dovepress.com/gang-membership-and-marijuana-use-among-african-american-female-adoles-peer-reviewed-fulltext-article-SAR

26. Loiola AA, Amate EM, Hoefel MGL, Carneiro FF. Determinantes sociais da violência na saúde de populações da América Latina. Rev Eletr Gestão Saúde [Internet]. 2014[cited 2016 Jul 25];6(2):1786-804. Available from: http://periodicos.unb.br/index.php/rgs/article/ view/22501/0

27. Costa APS, Oliveira DA, Rodrigues MP, Ferreira MAF. Violência doméstica e abuso de álcool e drogas na adolescência. Rev Ciênc Plur[Internet]. 2015[cited 2016 Jun 08];1(2):48-56. Available from: https://periodicos.ufrn.br/rcp/article/view/7616/5658

28. Cordeiro KCC, Santos, RM, Gomes NP, Melo DS, Mota RS, Couto TM. Formação profissional e notificação da violência contra a mulher. Rev Baiana Enferm [Internet]. 2015[cited 2017 Mar 25];29(3):209-17. Available from: https://portalseer.ufba.br/index.php/ 
enfermagem/article/view/13029

29. Silva MAI, Silva JL, Pereira BO, Oliveira WA, Medeiros M. The view of teachers on bullying and implications for nursing. Rev Esc Enferm USP[Internet]. 2014[cited 2016 Aug 10];48(4):723-30. Available from: http://www.scielo.br/pdf/reeusp/v48n4/0080-6234reeusp-48-04-723.pdf 